\title{
The Speculative Frontier: Real Estate, Governance and Occupancy on the Metropolitan Periphery
}

\section{Ashima Sood}

\section{(2) OpenEdition}

\section{Journals}

\section{Electronic version}

URL: https://journals.openedition.org/samaj/7204

DOI: $10.4000 /$ samaj.7204

ISSN: $1960-6060$

\section{Publisher}

Association pour la recherche sur l'Asie du Sud (ARAS)

\section{Electronic reference}

Ashima Sood, "The Speculative Frontier: Real Estate, Governance and Occupancy on the Metropolitan Periphery", South Asia Multidisciplinary Academic Journal [Online], 26 | 2021, Online since 10 March 2021, connection on 11 May 2021. URL: http://journals.openedition.org/samaj/7204 ; DOI: https:// doi.org/10.4000/samaj.7204

This text was automatically generated on 11 May 2021.

\section{c) $(1) \& \Theta$}

This work is licensed under a Creative Commons Attribution-NonCommercial-NoDerivatives 4.0 International License. 


\title{
The Speculative Frontier: Real Estate, Governance and Occupancy on the Metropolitan Periphery
}

\author{
Ashima Sood
}

\section{Introduction: speculative frontiers}

1 In July 2017, a domestic worker went missing in Mahagun Moderne, a middle-class gated community in Sector 78 of Noida or New Okhla Industrial Development Area, a satellite township on the eastern periphery of Delhi National Capital Region (NCR) (Dey 2017). ${ }^{1}$ The maid Zohra Bibi was eventually found within the boundaries of the development after her husband and neighbors entered Moderne by force to search for her. But the episode did not end there. Over the course of the next ten days, informal shops and shanties in the vicinity of Moderne, where Bibi lived, were demolished based on the complaints of Moderne residents (The Hindu 2017).

2 The basti (slum) residents' defiant transgression of the rules of separation enforced by the gated community and the subsequent retribution by the homeowners activated the anxieties that shape the interface between India's elite enclaves and their surroundings. With nearly 2,800 flats, of which about 2,000 were occupied as of July 2017 (Dey 2017), settings like Mahagun Moderne present a peri-urban territory that is being remade by real estate capital (Gururani and Dasgupta 2018:42). Built by private capital and inhabited by an assertive middle class, Moderne exemplifies in many ways the unfolding of the Southern "real estate turn" (Shatkin 2017) in metropolitan peripheries across India.

The social, political and economic implications of the Moderne case, as well as the larger phenomena it embodies, have been widely investigated. However, this paper takes as its point of departure two dimensions of this case that have received relatively little attention. First is its location in a rapidly transforming satellite city outside the metropolitan core of Delhi, a spatial periphery being reshaped by the dynamics of real 
estate capital flows. Second is the nature of its local governance under the jurisdiction of the Noida Authority, a planning parastatal that doubles as a (non-representative) municipal government. What can these aspects of the Moderne case tell us about the larger landscape of peripheral urbanization in India?

This paper theorizes these parallel dimensions of this "speculative" frontier-new periurban geographies being created by the forces of real estate development and the transitional and specialized forms of local government emerging in these territories.

5 In other words, the term "speculative" is used here in two senses. First, it describes the shifting, half-made but also conjectural territories of real estate capital that anchor new modes (and nodes) of place-making in the post-2000 peri-urban landscape (Kundu 2016). The geography of this speculative frontier is outlined through a novel database of investments in real estate capacity that present an essentially metropolitan landscape of privately-and largely nationally-financed housing construction and commercial projects. Findings from our database buttress scholarship that highlights the pivotal role of Indian private capital in building these real estate projects (Rouanet and Halbert 2016; Raman 2016). In this way, the paper trains a quantitative lens onto the "frontier urbanism" theorized by Gururani and Dasgupta (2018) -"a volatile and active landscape, caught in a vortex of change, a place full of potential but also of perils," "simultaneously inside and outside of the regimes of capitalist accumulation" (p. 42).

6 Second, the paper examines how forces of "speculative urbanism" (Goldman 2011a, 2011b)-defined by local government responses to real estate financial flows-play out in the peri-urban. In doing so, the paper contributes to an understanding of speculative "peri-urbanism," by highlighting how the form of local government shapes "speculative governance," i.e., how "state relations, urban citizenship, rights and rules of access" are being reconfigured in the wake of city-making projects on the "rural" periphery (Goldman 2011a:556).

7 In institutional economics terms, governance is understood broadly as the rules that regulate allocation and distribution of resources to end uses and users. This paper draws attention to the form of local government as the key dimension of governance. The diversity of specialized and provisional governance arrangements seen in the Hyderabad case as well as the exceptional reign of the Noida Authority helps establish a typology of the modes of government that characterize the speculative frontier (also see Shaw 2018). This typology of specialized and exceptional modalities of government is best understood in contrast to the municipal governments expected to manage urban areas, especially with the enactment of the $74^{\text {th }}$ Constitutional Amendment Act (Kennedy and Sood 2019; Sood and Kennedy 2020; Follmann 2015).

8 As Samanta (2014) reminds us, the statutory and census definitions of urban settlements do not necessarily converge. If the urban is the area administered by the municipal government that embodies the norm of the $74^{\text {th }}$ Constitutional Amendment, the peri-urban almost by definition lies outside the jurisdiction of this norm.

9 To understand this dichotomy, it helps to pay attention to the official routes through which areas are declared "urban" in India. These constitute two major categoriesstatutory towns and census towns. The former has an urban local body (ULB) such as a municipal corporation, municipal council, municipality or a Nagar Panchayat, based on population criteria defined under the $74^{\text {th }}$ Constitutional Amendment Act. ${ }^{2}$ The designation of census town, however, comes through a determination by the Census 
authorities that an area meets its tri-fold definition of the "urban" based on population, density and non-farm profile of the male workforce (Pradhan 2013). In the metropolitan core of agglomerations like the NCR or Greater Hyderabad, the municipal corporation(s) serve as statutory ULBs. On the peripheries, however, this disjunction between the census and the statutory gives rise to the phenomenon of "unrecognized" or "denied" urbanization-"territories [that] have been declared 'urban' by the census, but have not been declared 'statutory urban' by the state" (Samanta 2014:55).

The disparate geographies of Noida and Greater Hyderabad are, thus, settings where the census and statutory definitions of the urban i.e., the modality and norm of governance come to diverge. Peri-urban spaces, in this analysis, thus emerge as the arena where the tensions between urban growth and its governance unfold. Even more simply, the peri-urban is the arena where local bodies that meet the $74^{\text {th }}$ CAA's requirement of representative ULBs in urban areas are missing or unstable.

11 The two case studies of Greater Hyderabad and Noida instantiate seemingly opposed trajectories for the transitional and exceptional modes of government that characterize the speculative frontier relative to the metropolitan core. In the former case, the multiplicity of these local bodies and parastatals can lead to fragmentation and jurisdictional gaps. In the second case, the concentration of municipal powers and functions within the ambit of the Noida Authority encourages functional overreach.

In this way, this paper further characterizes how modalities of governance are shaped by investment in the speculative frontier as "a zone beyond which further expansion is possible" (Moore 2000 quoted in Gillespie 2020:15). Like Dupont (2007), this paper sees the peri-urban "as a space whose use corresponds to diverse and often conflicting stakes, indicative of processes signifying a political and societal vision of the city and access" (p. 89).

13 In particular, I argue that in both the cases of Noida and Greater Hyderabad, these speculative peri-urbanisms serve to undercut occupancy (peri-)urbanisms by subaltern groups. Empowering and responding to propertied and entrepreneurial agendas, they further undermine the most disempowered citizens. The absence of elected and responsive representatives to adjudicate the claims of migrants and working-class denizens in places such as Mahagun Moderne thus places the larger problematic of the right to the city in jeopardy-the "call to all inhabitants in the city to contribute to "the production of urban space" (Lefebvre 1991) and "appropriate its uses" (Zérah et al. 2011) in peri-urban India.

\section{Occupancy and Speculative Peri-urbanisms}

Engaging with the theme of this special issue, this paper asks-what is urban about this putative terrain of the peri-urban? The paper's contribution lies in delineating an interpretive framework informed by a macro-portrait of the speculative frontier and elucidated through case studies of governance dynamics in the two settings of Greater Hyderabad and Noida. Drawing its basic conceptual scaffold from the theses of speculative and frontier urbanism, the paper is interested in both the precise modalities of speculative governance as well as in their repercussions for the political economy of the peri-urban.

In this endeavor, I bring into conversation several literatures that have spoken to one another rarely, if at all, especially against the backdrop of the peri-urban. In particular, 
the paper connects three broad bodies of scholarship. One is the broader debate around the "real estate turn" described by Shatkin (2016) and defined in a later section. The work of Rouanet and Halbert (2014), Raman (2016) and Goldman (2011a, 2011b) fall in this rubric. Second is incipient literature on the political economy of "unrecognized" or "denied" urbanization alluded to above (Samanta 2014; Pradhan 2013). In tracing out the repercussions of speculative governance on the peri-urban frontier, the notions of internal and external governance prove useful (Sood 2015:1362). And last but not least is the framework of occupancy urbanism (Benjamin 2008), which underlines the role of "vote bank politics" in helping poor groups in both "claiming public services and safeguarding territorial claims" (p. 720). Scholarship on the frontier and speculative urbanisms has been preoccupied with matters of land assembly, planning and policy (Shatkin 2011; Goldman 2011a, 2011b; Balakrishnan 2019; Gururani and Dasgupta 2018; Gillespie 2020). This paper aims to recenter questions of local governance in debates around the peri-urban frontier (cf. Dupont 2007; Kennedy 2007; Idiculla 2016; Sood 2015; Shaw 2018).

In analyzing non-statutory or denied urbanization in the two cases of Greater Hyderabad and Noida, this paper draws on Samanta's (2014) argument that the resolution of these tensions lies not in statistical or administrative fixes but political decision-making. What kinds of political contestation are evident in the two case studies analyzed in this paper? Although there has been no local elected body in Noida over the past four decades since its development, recent attempts by the state government to introduce a municipal corporation have faced pushback. Similarly, in Hyderabad outgrowths, where a variety of local governments jostle each other, this instability often arises in the political economy of real estate-led peri-urban development itself.

The Greater Hyderabad case further reveals how the salience of real estate dynamics shapes the territoriality of this peri-urban terrain. The spatiality and history of periurban transformation in these locations, I contend, have the potential to illuminate wider trajectories of speculative government on metropolitan peripheries. An important manifestation on the speculative frontier are tussles around the "politics of classification" of urbanizing areas (Samanta 2014). In turn, this political economy of government form leads to a multiplication of local bodies, with varying degrees of autonomy and democratic accountability. These often share jurisdictional borders but lack clearly defined channels for external governance that would allow coordination across functions "such as public infrastructure and collective goods provision, regional and spatial growth planning and management, public finances, natural resource allocation, among others" (Sood 2015:1363). In contrast to the multiplicity of agencies on the peri-urban frontier, the Greater Hyderabad Municipal Corporation allows for clearer institutional channels for communication and coordination across adjoining "circles." In some ways, it can be said to define the central jurisdiction in the metropolitan region, the urban core against which the peri-urban multiplicity can be defined.

These governance regimes have implications for the right to the city in profound ways for the most vulnerable populations as the Noida case underlines. The nature of local government remains central to this mediation, as theorizations of occupancy urbanism remind us (Benjamin 2007, 2008) because they determine how citizenship can be negotiated in domains ranging from public spaces to water access (Gajendran 2016). 

draws on secondary sources, supplemented with longstanding primary fieldwork in the Greater Hyderabad area. Although the analytical methodology in the two case studies of Noida and Greater Hyderabad differs substantially, the two cases together offer illuminating contrasts and continuities when it comes to the typologies and effects of local government. The paper combines secondary and primary data, both qualitative and quantitative, to advance the characterization of this peri-metropolitan speculative frontier. This methodologically eclectic approach is necessitated by theoretical and empirical gaps in current debates on the peri-urban in India and the Global South more generally. Thus, this paper begins by sketching a hitherto unexplored macro-landscape of real estate investments in India before turning to case studies of peri-urban government that shape this frontier.

The quantitative contours of the speculative frontiers, mapped in the next section, are based on a database of medium to large-scale investments in housing or commercial real estate capacity. The following section revisits the Noida case through news-reports and documentary sources to examine the role of local governance vis-à-vis occupancy urbanisms. The case of Greater Hyderabad, drawing on fieldwork over several years, subsequently synthesizes primary fieldwork and secondary sources to sketch out the emerging landscape of governance frameworks on the speculative frontier.

\section{Peri-urban/greenfield: Gauging the speculative Frontier}

21 If real estate activity is a major driver of outcomes on the speculative frontier, what is its geographic scope and spread? There have been relatively few attempts at answering this question. ${ }^{3}$ The paper aims to fill this gap by drawing on data from a database of investments in productive capacity created by the Centre for Monitoring the Indian Economy (CMIE). This database tracks investments in productive capacity in projects exceeding INR 10 million (or one crore) across sectors. For the analysis reported in this section, out of the multitudes of sectors contained in the database, the focus was on two related real estate verticals-housing construction and commercial complexes.

The CapEx database analyzed here compiles information from a variety of sources in the public domain as well as direct contact with promoters. It covers the period from 1996-2018, with most projects becoming visible only in $1998 .{ }^{4}$ As the CMIE data tracks investments rather than completed projects alone, it helps glean an "intent" to urbanize as revealed through investments undertaken in housing and commercial developments. Many investments can and do fail. ${ }^{5}$ Accordingly, the twenty-year span of the analysis presented here categorizes projects by their status, coded into completed, outstanding or under construction, as well as abandoned or shelved. The database also contains information on promoters, co-promoters, associates, life-cycle events as well as location, among other variables. ${ }^{6}$ Since CMIE captures project information through media reports as well as some interviews with developers, it is subject to issues in reporting and may represent an undercount of projects across all status categories.

23 Although the larger aim of the database analysis was to identify the largest urban integrated megaprojects (UIMs) (Shatkin 2011), this section presents findings from the larger populations of projects. ${ }^{7}$ Note that the investments analyzed here include more 
quotidian examples of city-making in contrast to megaprojects such as the infrastructure corridors, which have received more scholarly attention (Sami and Anand 2016; Balakrishnan 2013; Nair 2015). In our analysis, the largest UIMs are a fraction of a larger incursion of private capital into the built environment in India's metropolises. About $6 \%$ of projects in the database have been shelved (Figure 1), but in the Greater Hyderabad districts, this number is closer to $10 \%$. Worth noting is the sheer preponderance of Indian relative to foreign promoters, state or public-private partnership actors (Figure 2). National and local capital circuits are, as argued elsewhere, the key to "landing" real estate financial flows (Halbert and Rouanet 2014; Rouanet and Halbert 2016; Raman 2016). As Figure 2 shows, across status categories, projects led by private Indian promoters average well over three-fourths of all projects. Although the database also provides information on other Project Associates, international and public-private partnerships (PPPs) represent small proportions of the total. (PPPs appear slightly more likely to have failed in these summary statistics.)

Figure 1: The majority of projects in the database were outstanding or under construction as of 2018, all-India

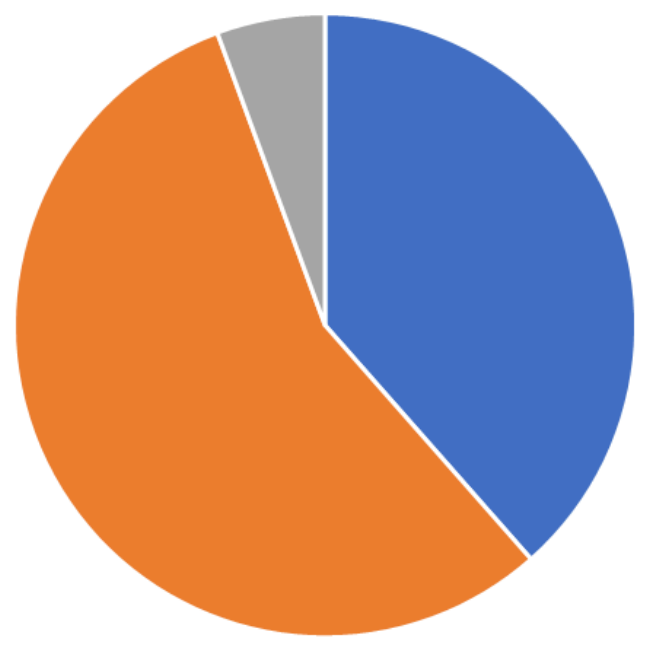

- Project Status:Completed = Project Status: Outstanding = Project Status: Shelved 
Figure 2: All projects by ownership and project status are predominantly privately promoted, allIndia

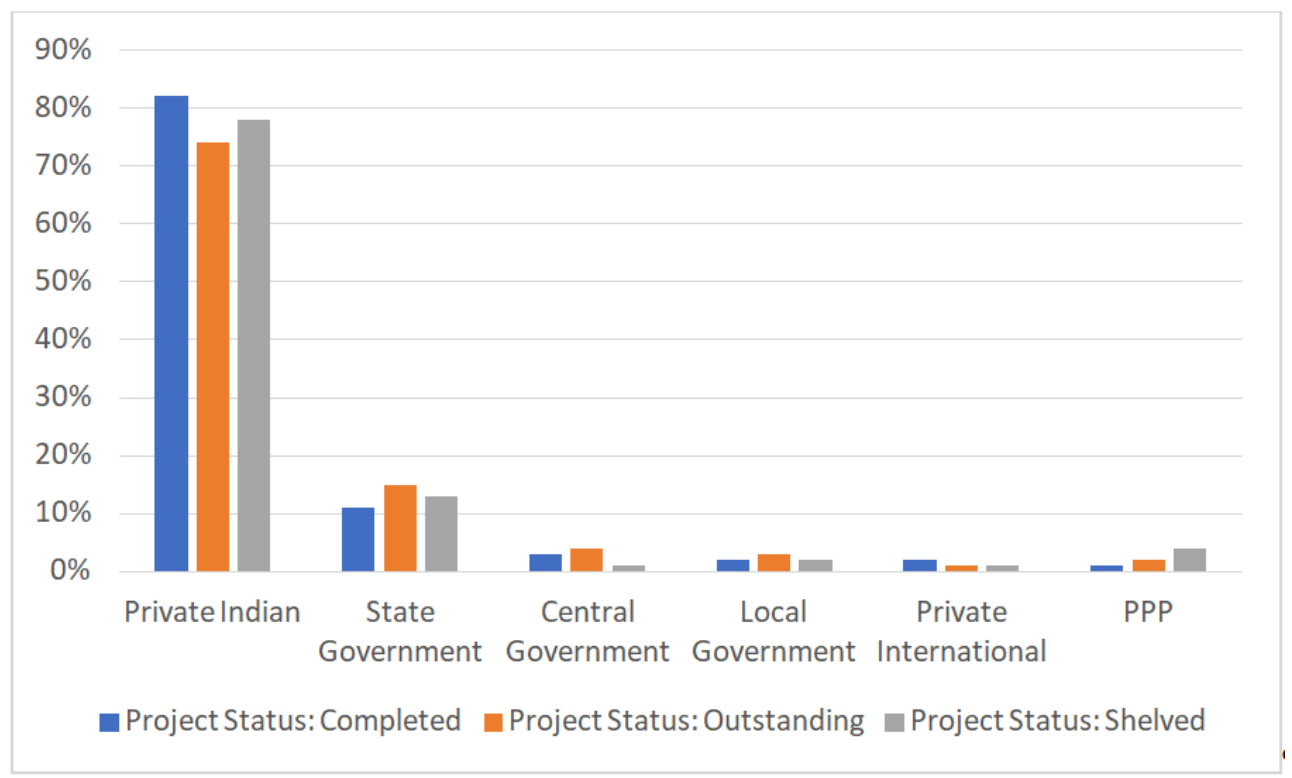

Source: CMIE; Author's database

Note: All projects by project status should add up to 100\%, though there may be rounding errors.

Perhaps the most relevant findings from this database pertain to location. Nearly twothirds of all completed real estate housing and commercial construction projects with an investment of over INR 10 million across India are located in one of India's top eight metropolitan regions (Figure 3; see also Figure 4). ${ }^{8}$ For projects of equivalent size and scope that were "outstanding" or under construction, the corresponding figure dropped to about $60 \%$. Together these eight metropolitan areas comprise just about a quarter of India's urban population of over 460 million in 2018..$^{9}$ The sheer spatial concentration of real estate construction activity makes it abundantly clear that this phenomenon is a feature not simply of urban but more specifically metropolitan India. 
Figure 3: The large majority of projects, regardless of project status, are located in million-plus cities, all-India

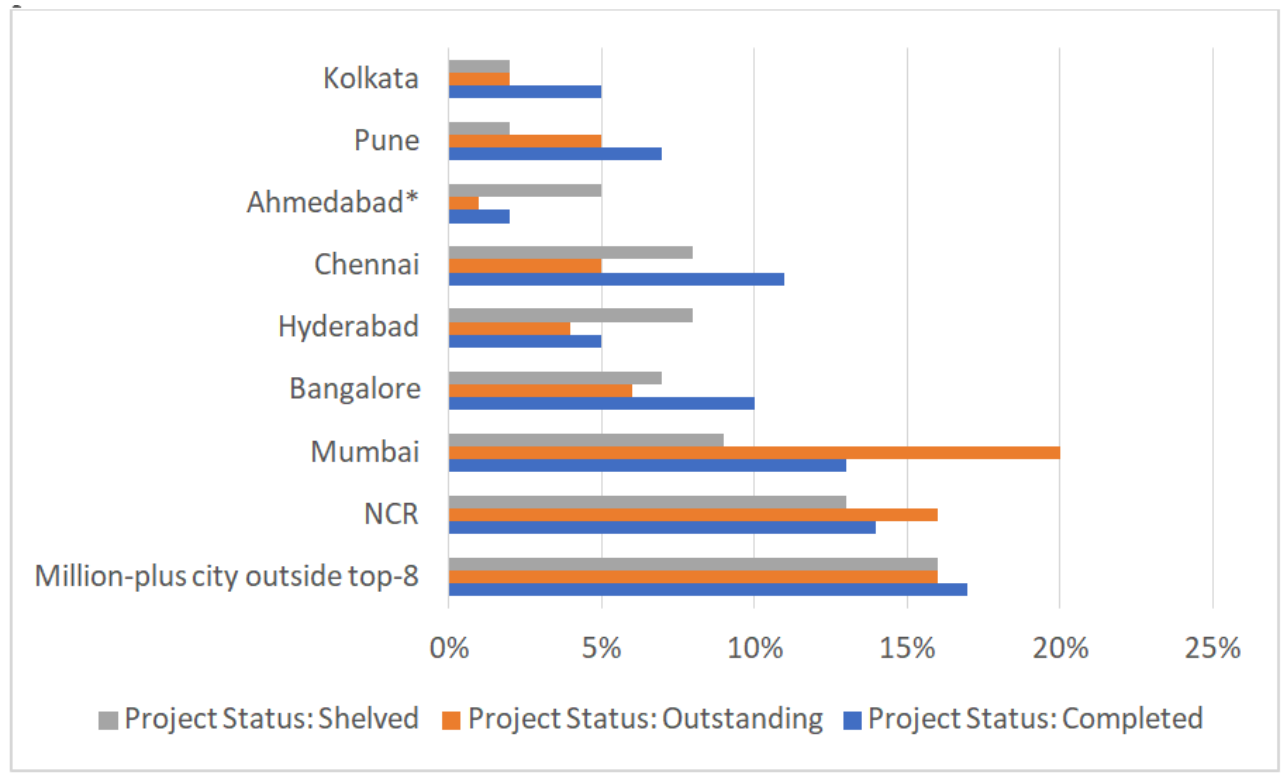

Source: CMIE; Author's database

Notes: All projects by project status do not add up to $100 \%$ because the chart does not include urban areas outside million-plus cities. *Ahmedabad does not include the adjoining Gandhinagar Urban Development Authority area. Hence these numbers may be undercounted.

Figure 4:Completed Projects show clear clustering in top eight million-plus urban agglomerations, all-India.

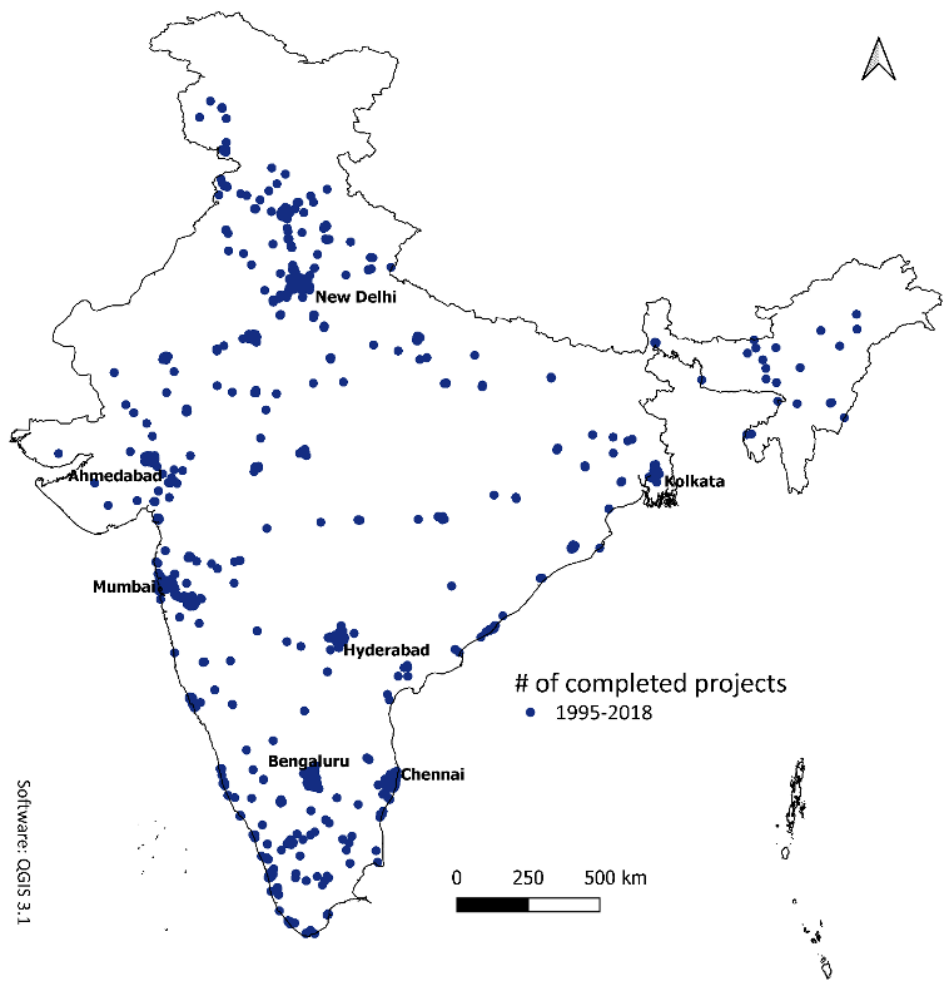

Source: Map by Shreya Basu, based on a database compiled by Ashima Sood and Tarun Jain, with help from Prerna Dokania. 
To reiterate the highly concentrated nature of this activity, one more data point deserves mention. About 16-17\% of India's urban population lives in million-plus cities outside the top eight metropolitan areas, according to the 2011 Census data on urban agglomerations..$^{10}$ This is roughly in line with the representation of projects in these sites in this database (Figure 3). However, combining data from all million-plus urban agglomerations, it would appear that only about a quarter of outstanding projects are coming up outside million-plus urban centers. These smaller urban centers that house over half of India's total urban population actually house an even smaller proportion of completed projects, though they have a higher proportion of what appear to be failed projects.

Figure 5: Completed Projects by Ownership show that publicly promoted projects are more geographically dispersed, all-India

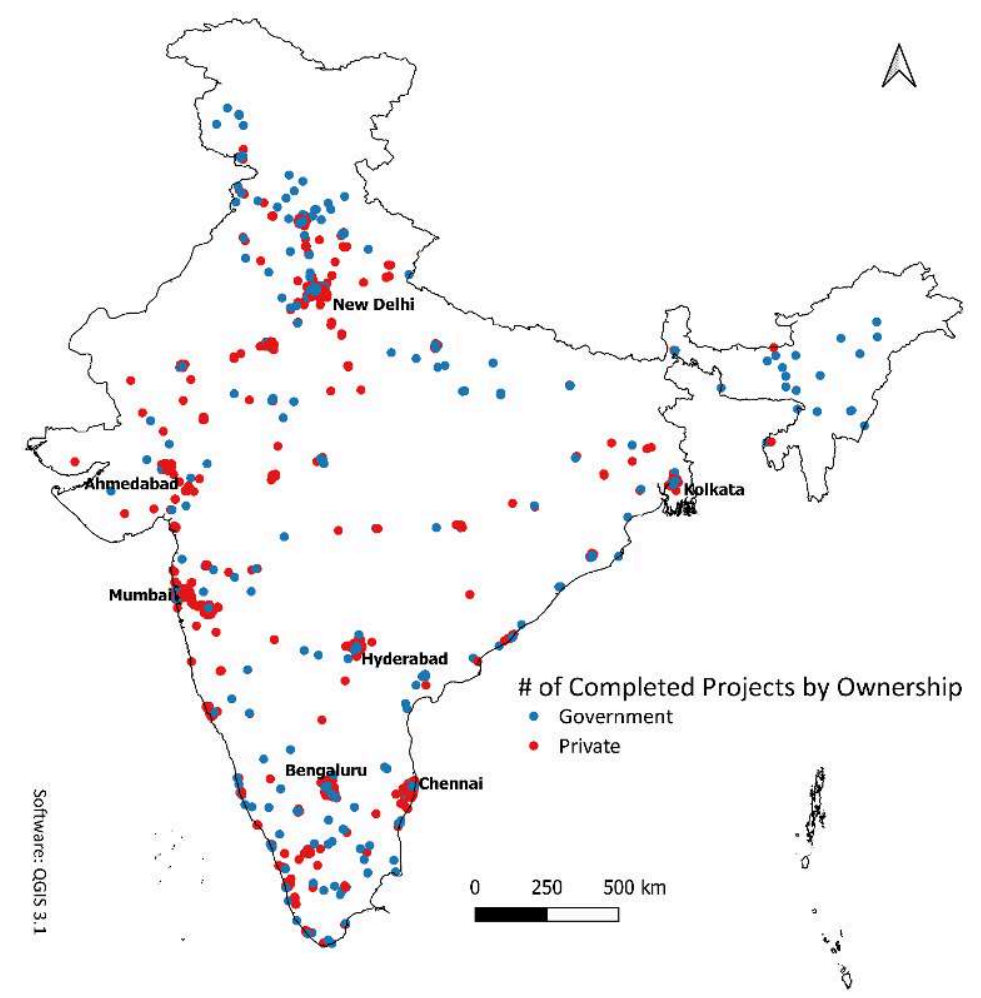

Source: Map by Shreya Basu, based on a database compiled by Ashima Sood and Tarun Jain, with help from Prerna Dokania.

Figure 4 and Figure 5 confer nuance to the forces driving this spatial concentration. ${ }^{11}$ First, as Figure 5 shows, projects sponsored by central, state and to a degree, local governments are spatially more dispersed. However, the fact that the map of projects completed even in 2013-19 misses large swathes of central and eastern India suggests a "spatial rift" in India's regional geography that mirrors other axes of disadvantage (Balakrishnan 2020).

What does it mean that housing and commercial capacity construction is so overwhelmingly a metropolitan phenomenon? These findings offer provocative insight into what the future map of urban India may look like, based on current patterns of predominantly private, but also a public investment into building capacity. Informal, sometimes illegal yet indubitably private initiative has always shaped the once peri- 
urban frontier, whether in the Sangam Vihars of Delhi, the gunthewadis of Maharashtra or the Bombay Hotels of Ahmedabad (Bhide 2013; Desai and Sanghvi 2017; Dubey 2018). The spatiality of the speculative frontier outlined here suggests other facets to peri-urban, and especially peri-metropolitan, India (Also see Arabindoo 2009; Raman 2016; Rouanet and Halbert 2015). ${ }^{12}$ It must be noted that the peri-urban landscape outlined here is in many ways far from the vision of autoconstructed peripheral urbanization that makes possible claims to citizenship (Caldeira 2017). To a large extent, this reflects our focus on the spatial imprint of organized and capitalintensive real estate-led peri-urbanization.

These modalities of local government can be crucial to the unfolding of the policy agenda embedded in the real estate turn.

\section{Occupancy Urbanism in the Urban Periphery}

Consisting of completed, under construction or abandoned projects, the real-estate portrait mapped out in a previous section is primarily a phenomenon of the metropolitan periphery. This section focuses on the unusual forms of local government that proliferate in these settings. In so doing, it gives substance to what Shatkin (2016) describes as the "real estate turn": "the reform agendas" that encourage "a more commercial orientation in their land management" ( $p$ 142). Unlike peri-urban Hyderabad, Noida benefits from a unified governance framework in the form of the Noida Authority. Much more responsive to builders, owners and industrialists than it is to workers, this is a government that renders occupancy urbanism ineffectual (Benjamin 2008).

30 A planned satellite city inaugurated during the inauspicious days of the Emergency (Schindler and Kishore 2015; Dubey 2018), Noida has evolved from a planned agglomeration for small-scale industry to a hub for India's high-end information technology and enabled services economy (Schindler and Kishore 2015). The result is an uneven mix of high-end residential and commercial development interspersed with industrial clusters and working-class bastis. Situated on the eastern quadrant of the Delhi NCR, Sector 78 is not far from the center of the NOIDA. In maps, Sector 78 shows up as a squat battleship shape, a world of gated communities, with names like Hyde Park, Morpheus Green and Windsor Court, including many Mahagun developments. A mosque juts out in the far northwest corner of the Sector 78 map (See Figure 6). ${ }^{13}$ 
Figure 6: Sector 78, NOIDA

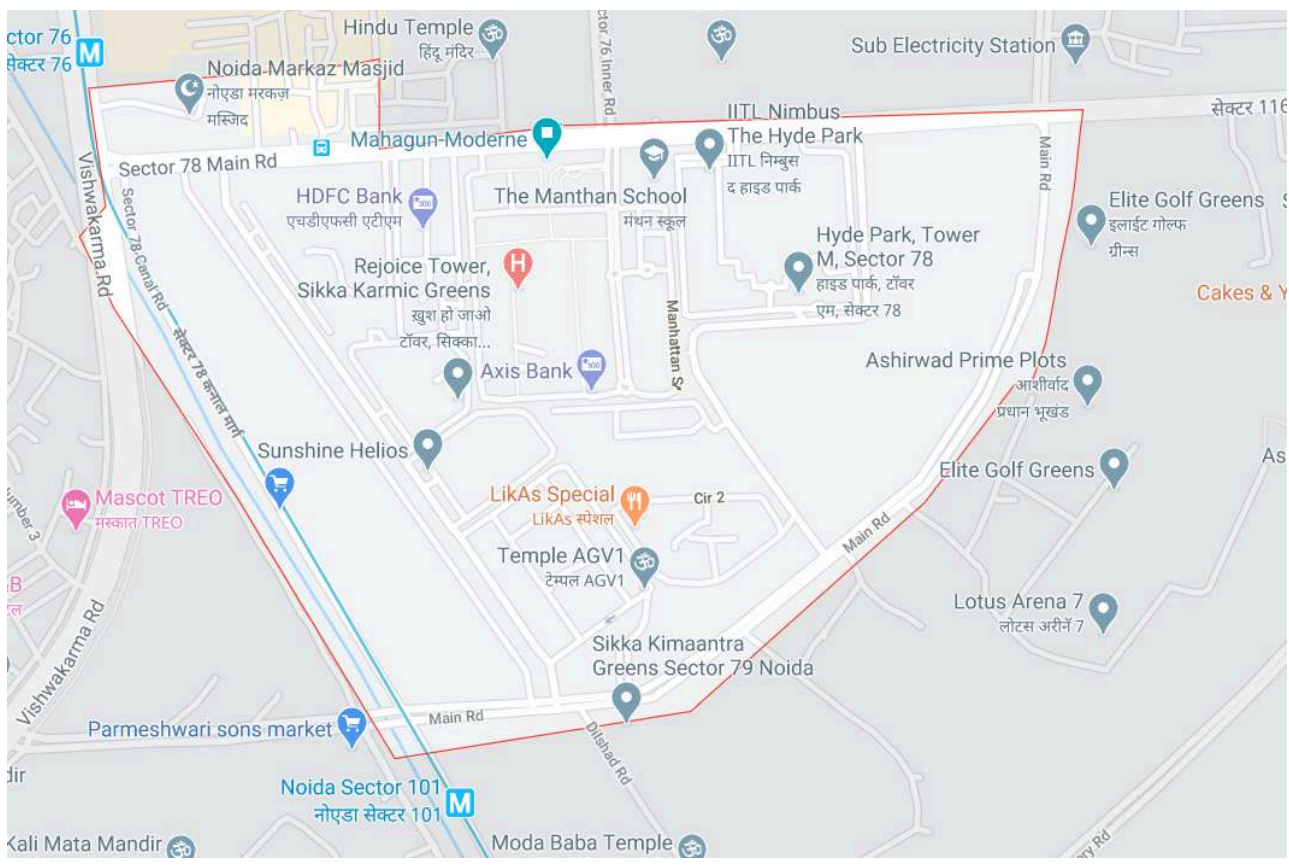

Source: Google Maps

With its many conflicting, shifting accounts, the Noida Sector 78 episode highlighted at the outset of this chapter appears to be a generative setting for investigating the governance dynamics in the speculative frontier. As I argue below, a link may be made between the proliferation of private residential development aimed at middle-class Indians, the exceptional form of urban government in Noida and the viability of occupancy peri-urbanisms.

The denial of occupation rights witnessed in the Mahagun makes it possible to delineate these logics. While recent scholarship on the Noida Authority views its function through the lens of planning (Dubey 2018), the reading here revisits contestations around occupancy as issues of (internal and external) governance. In this way, it aims to re-inscribe local government as the arena where the political economy of urban development is enacted. Home to enclaves created by spatially targeted infrastructure development and maintained in some ways by the instrumentalization of urban governance modalities (Kennedy and Zérah 2008), the speculative frontier emerges as a deeply divided territory, one that actively subverts the possibility of occupancy (Benjamin 2008; Chatterjee 2004; Bhattacharya and Sanyal 2011).

These two worlds came into conflict in Mahagun Moderne when a ragtag group stormed the high gates of the development after the domestic worker failed to return from her daily shift (Gupta 2017; Dey 2017; Mohan 2017). After the domestic worker Zohra Bibi was found, accounts of the events that led up to her disappearance rapidly took on a "she said, he said" character, as Zohra Bibi and her employers, the Sethis, exchanged claims about whether it was Bibi's wages or the Sethi's cash that was stolen (Gupta 2017; Dey 2017; Mohan 2017). Even more remarkable, even the site and circumstances of Bibi's recovery became contested. While Bibi herself claimed to have been held captive by the Sethis, the police countered that she was found in the basement of a building where she had taken shelter after being assaulted (Dey 2017). 


\section{manifested in the architecture of boundary walls and high gates (Maanvi 2017;} Dey 2017). At the same time, for all their physical, social and recreational facilities, developments like Moderne remain deeply reliant on the "survival circuit" of the flow of labor and materials from their surrounding areas (Bhattacharya and Sanyal 2011:44). Through the 1980s, this interdependence between the Indian middle classes, who powered the accumulation economy, and actors in the subsistence economy, found expression first in the politics of patronage and then in competitive "vote-bank" politics (Chatterjee 2004). (Noida Authority) on the side of the Moderne residents in 2017 speaks directly not just to the changing political economy of Indian cities but also the framework of local governance through which it is articulated. Dubey (2018) has previously analyzed the Noida Authority's hostile stance towards organic informal growth in Khora village. "City of our dreams," Noida may represent the bourgeois frontier of civil society, with a politics mediated through the genteel auspices of the Resident Welfare Association (RWA) and industries and trade associations (Coelho et al. 2013).

Despite having a population of over 600,000 (Census of India 2011b), Noida lacks an elected municipal government (Express News Service 2019). Instead, the Noida 
Authority, constituted under the Uttar Pradesh Industrial Development Act of 1976, performs many municipal functions in addition to its mandate as a planning and development agency (see also Dubey 2018). ${ }^{14}$ Noida's RWAs have, in recent years, played a complicated role in upholding this regime. ${ }^{15}$ When the idea of a municipal corporation for Gautam Buddha Nagar comprising Noida, Greater Noida and Yamuna Expressway was first mooted, several RWA bodies, as well as industry and trade associations, came out against the proposal (TNN 2017a). At a meeting convened in December 2017, a larger array of groups-ranging from the Federation of Noida Resident Welfare Associations (FONRWA) to the Noida Entrepreneurs Association (NEA) and the local chapter of the Confederation of Real Estate Developers' Association of India (CREDAI)-opposed the need for a municipal body. Instead, it was reported that the demand was for "civic byelaws ... to fix the accountability of residents and the Authority towards the city" (Bahl 2017).

Other reports indicated at least some sections of the RWAs and local "social organisations" were pressing for the creation of an elected municipal government (TNN 2017b). ${ }^{16}$ Interestingly, the debate on the proposed municipal body was revived in 2020 on the insistence of urban villages under the Noida Authority's jurisdiction (TNN 2020) who complained about a lack of hearing in the authority's offices with village heads stripped of their mediating role.

41 Noida thus instantiates the speculative frontier, as a territory not only constructed by but also governed in meaningful ways by propertied interests such as RWAs and industry associations. The resistance by the basti dwellers at Mahagun Moderne and the fierce reaction to it putatively highlight the emerging socio-spatial frontier of the periurban as "an oppositional site" (Benjamin 2007:539). In more subtle ways, however, they call the limits of this resistance into question. The Mahagun Moderne episode suggests failure of processes that might embolden "de facto tenure" and occupancy by poor groups (Benjamin 2007:552).

In the occupancy urbanism framework, resonating with Chatterjee's (2004) conceptualization of "political society," vote bank politics alludes to claim-making by poor groups that are supported by access to "voter lists in municipal elections" (Benjamin 2008:719). The modalities of representation also have a role to play, as Benjamin (2007) points out:

The importance of local councillors is not just that they are part of a democratic system shaped by voting (and perhaps Constitutional decentralisation), but rather that they are embedded in society. (P. 550)

The analysis here suggests that the local "vote bank" politics that would offer a counterpoint to the majoritarian interests of the central and state governments may have been undercut by the absence of a municipal corporation. The absence of representative local politics in Noida Sector 78 manifested itself in a lack of institutional platforms that would otherwise encourage electoral contestation between propertied and non-propertied interests within the territory of the Noida Authority. In other words, this lack of politics undermined internal governance, "the actors, institutions and mechanisms available for the realisation of collective goals within the ... township" (Sood 2015:1362). Instead, the institutional void showed itself as a gap in external governance. It allowed the gated community to wield more substantive power through the levers of the state precisely in opposition to collective action by the basti's migrant community. 

of this speculative frontier.

\section{Governance in Peri-urban Hyderabad}

The scenes of overt conflict in Noida Sector 78 are far from typical on the peri-urban interface, where forms of co-habitation, even if uneasy, often prevail, as Kundu's (2016) study of place-making on Rajarhat new town as also Xie's (this issue) comparative analysis of Hyderabad and Chengdu demonstrate. ${ }^{17}$ In Greater Hyderabad, the evolution of governance arrangements on the speculative frontier has been a messy and contested process with fragmentation as its outcome.

In this section, the case of Greater Hyderabad thus delineates the range of exceptional and provisional governance regimes that shape the frontier. Greater Hyderabad's speculative frontier typifies the bourgeois landscape of the "post-industrial globalized metropolis" (Chatterjee 2004). It pinpoints more precisely the spatial location of the pan-Indian metropolitan focus of construction activity. No more than just over a quarter of completed, outstanding and shelved projects in the five districts that wholly or partially comprised the metropolitan area were in the core city of the erstwhile Municipal Corporation of Hyderabad. Nearly a third were clustered in the erstwhile municipalities of Serilingampally and Kukatpally, which were incorporated into Greater Hyderabad Municipal Corporation (GHMC) at the time of its formation in 2007, and continue to be the hub of high-end real estate. Though the numbers presented here may overestimate the number of projects located in core municipal areas, they remain valuable for conferring rare insight into the magnitude and spatiality of the speculative frontier. ${ }^{18}$

In Greater Hyderabad, however, the state government and not the municipal corporation has been the entrepreneurial actor shaping the process of land transformation for purposes of IT-led development (Kennedy 2007; Kennedy 2014; Sood 2016; Mitra 2018). As in Goldman's Bangalore (2011a, 2011b), real estate plays by both the state and private actors have underpinned this expansion. The Growth Corridor on either side of the Outer Ring Road (ORR) that circles the city has unlocked large parcels of land critical to the realization of these plans (Mitra 2018).

A sense of the spatial extent of this frontier as defined by real estate projects is given in Figures 6 and 7. The comparison between completed versus outstanding projects illuminates its gradual movement overtime. The increasing prominence of state government projects in the core city has accompanied a westward clustering of private projects in Narsingi Municipality and its neighbors in Rajendranagar Mandal. While Figure 7 and Figure 8 highlight the spatial spread of housing construction projects from the database, Table 1 maps the intersections of planning and governance regimes that mark this terrain. 
Figure 7: Completed housing construction projects 1995-2018 in Greater Hyderabad are clustered outside the core pre-2007 Municipal Corporation of Hyderabad (MCH) areas

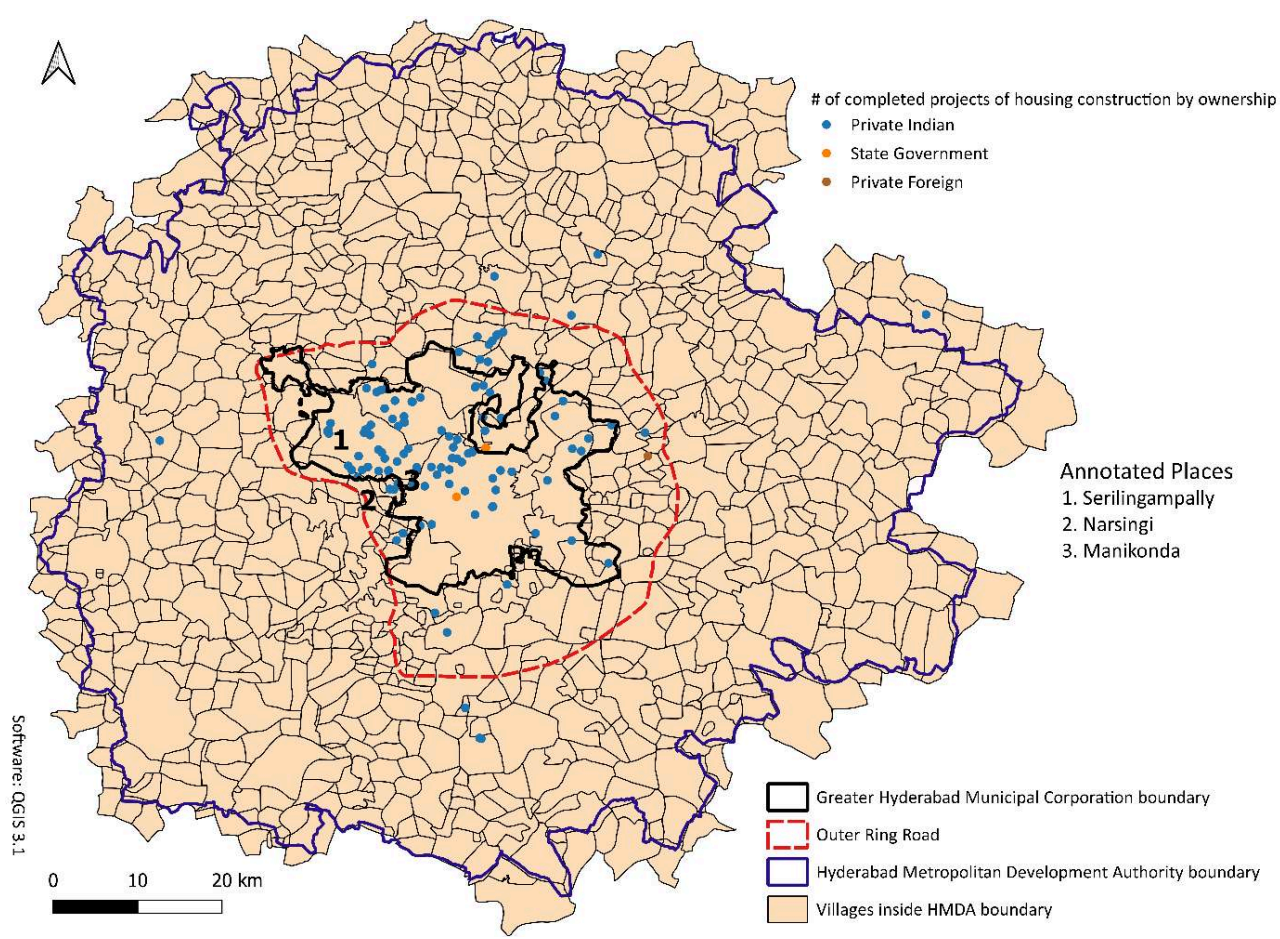

Source: Map by Shreya Basu, based on a database compiled by Ashima Sood and Tarun Jain, with help from Prerna Dokania.

Figure 8: Outstanding housing construction projects as of 2018 show increasing dispersion outside GHMC boundaries

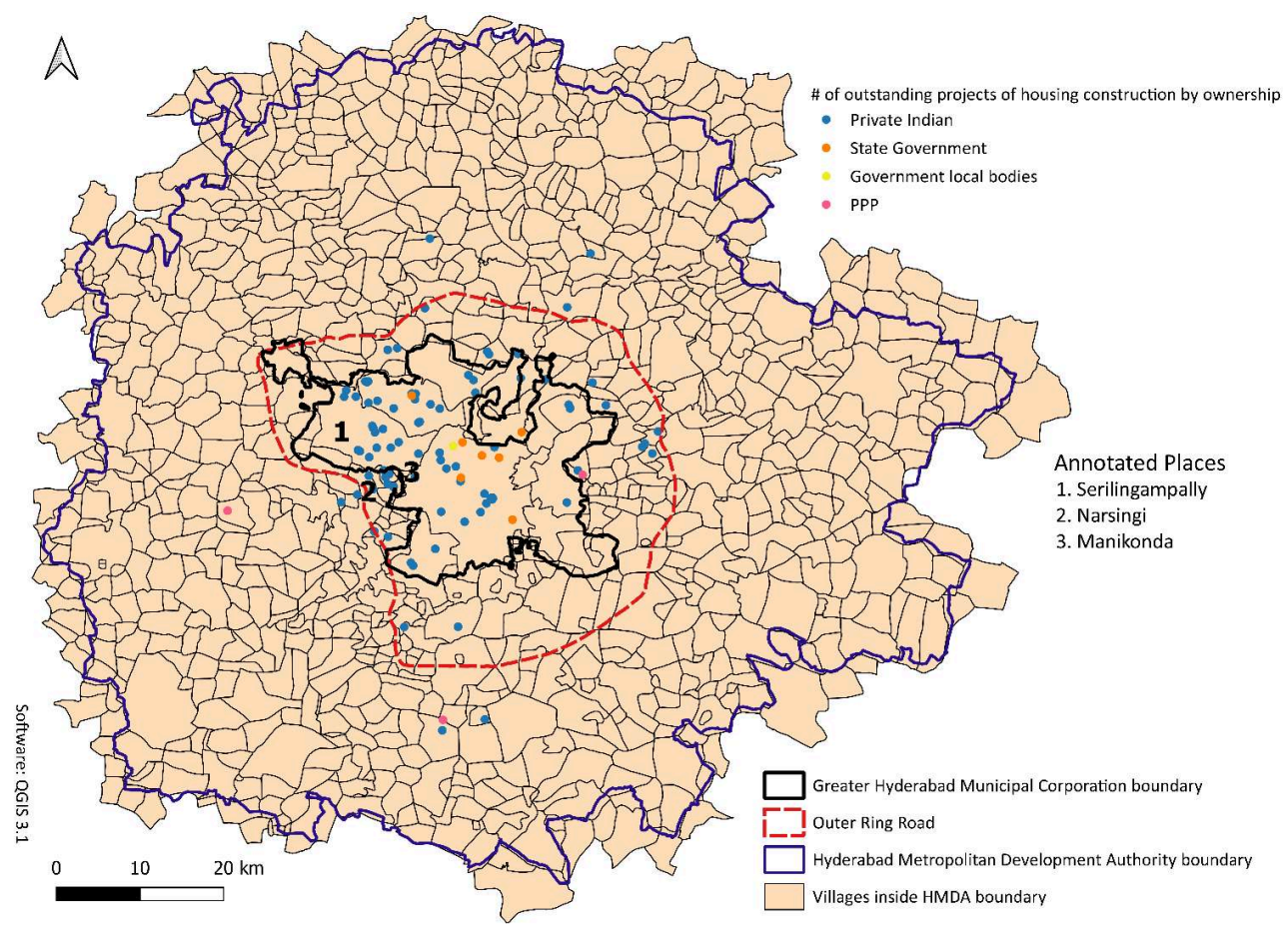

Source: Map by Shreya Basu, based on a database compiled by Ashima Sood and Tarun Jain, with help from Prerna Dokania. 
Focusing on localities that abut the growth corridor along the western stretch of the Outer Ring Road, this section attempts to highlight the fluid, uneven and fast-evolving jurisdictions that govern this geography. In so doing: it aims to answer two questions. First, to what extent does the definitional divergence in population and government criteria along the speculative frontier in Greater Hyderabad implicate the political economy of real estate? Second, what are the spatial manifestations-and repercussions -of the multiplicity of local bodies that crowd this frontier?

\section{Speculative Governance on the Peri-urban Frontier}

If the Greater Hyderabad Municipal Corporation defines the pivotal urban local body i.e., the municipal corporation, the variety of local governments on the metropolitan frontier have often arrayed themselves in opposition to it. It is useful, therefore, to recognize-and categorize-the diversity of government forms on this speculative frontier: exceptional regimes such as the Industrial Area Local Authority (IALA), transitional rural bodies such as Panchayats in census towns as well as municipalities which carve out smaller urban areas.

51 The first form of local government is an exceptional regime, the IALA, which in many ways resembles the Noida Authority, albeit on a smaller scale. It dots the territory of the GHMC, as Table 1 shows, in the Serilingampally circle but also beyond it (Kennedy and Sood 2019; Sood and Kennedy 2020). Devolving the powers and functions of the municipal government to the state's Industrial Infrastructure Corporation in industrial parks across Telangana, the IALA has been a critical "zoning technology" applied by the state government to advance its entrepreneurial agenda (Kennedy 2014; Ong 2006). This is an instrument that leverages a variety of "exemptions" and "flexible planning" modalities to shape land use and ease building regulations (Kennedy and Sood 2019; Sood 2016). Its chief use, however, lies in its public finances model, which allows the majority share of property tax collections to be retained for use in the tiny enclaves, while a smaller share is disbursed to the GHMC. ${ }^{19}$

Table 1: Select Settlements in the Hyderabad Metropolitan Development Authority (HMDA), Census 2011

\begin{tabular}{|c|c|c|}
\hline Administrative Unit & $\begin{array}{l}\text { Statutory } \\
\text { Classification }\end{array}$ & Current Status (where known) \\
\hline District: Hyderabad & $\begin{array}{l}\text { Greater } \quad \text { Hyderabad } \\
\text { Municipal }\end{array}$ & \\
\hline Serilingampally & $\begin{array}{l}\text { GHMC; part of } \\
\text { Rangareddy district }\end{array}$ & $\begin{array}{l}\text { Municipality incorporated into GHMC in } \\
\text { 2007; parts fall under IALA. }\end{array}$ \\
\hline $\begin{array}{l}\text { Kokapet, } \quad \text { Mandal: } \\
\text { Rajendranagar }\end{array}$ & Outgrowth & Part of Narsingi Municipality \\
\hline $\begin{array}{l}\text { Manikonda, Jagir and Khalsa, } \\
\text { Mandal: Rajendranagar }\end{array}$ & Outgrowth & $\begin{array}{l}\text { Parts still classified as a village; some parts } \\
\text { fall under IALA. Parts of Manikonda form a } \\
\text { new Municipality }\end{array}$ \\
\hline
\end{tabular}




\begin{tabular}{|lr|l|l|}
\hline $\begin{array}{l}\text { Puppalguda, } \\
\text { Rajendranagar }\end{array}$ & Mandal: & Outgrowth & $\begin{array}{l}\text { Some parts fall under Manikonda } \\
\text { Municipality }\end{array}$ \\
\hline $\begin{array}{l}\text { Narsingi, } \\
\text { Rajendranagar* }\end{array}$ & Mandal: & Census Town & Part of Narsingi Municipality \\
\hline $\begin{array}{l}\text { Tellapur, } \\
\text { Ramchandrapuram }\end{array}$ & Mandal: & Outgrowth & Tellapur municipality \\
\hline
\end{tabular}

Source: Census of India (2011a; 2011b; 2011c); TNN (2018); municipality websites 20

Note: *Narsingi now appears to include VN Pally village, mentioned below.

52 Even beyond the territory of the IALAs, tax considerations as much as land availability appeared to have shaped the governance dynamics in this stretch of Greater Hyderabad. Incorporation into a larger municipal body such as the GHMC may confer benefits but it also threatens to siphon away real estate surpluses in the form of property taxes elsewhere. This is the key tension that appears to guide the statutory classification of localities on this speculative frontier, as I show below.

Rural local bodies or panchayats (villages), are the second form of transitional government that exist on this speculative frontier. The census category of outgrowths -"viable units which emerge adjacent to, but outside the administrative limits of [statutory towns] ... not complete settlement units, like an entire village" (Pradhan 2013:43) represent a related typology. Panchayats often lack the capacity or the incentives to regulate land and their built environment, unlike the GHMC. In places like Manikonda and Puppalguda, this has encouraged the rise of unauthorized settlements amid suspect land deals. The resulting lax regulation proves useful for real estate actors at all scales (Staff Reporter 2013; Deccan Chronicle 2016).

There have been repeated attempts to incorporate these areas into the GHMC. One of the earliest such notifications came in 2011 when GHMC included Manikonda, Shamshabad, Vattinagulapally (VN Pally) ${ }^{21}$ and Narsingi in a list of 30 villages to be annexed (News18 2011). Despite the plan being revisited in 2013, it remained a nonstarter (Special Correspondent 2013) in the face of legal challenges, particularly by villagers from Manchirevula and Manikonda (TNN 2013). As late as 2018, news reports suggested the state government intended to merge the so-called IT corridor, consisting of Manikonda and Shamshabad, with the GHMC. Several other gram panchayats adjacent to the Nehru Outer Ring Road (ORR), including Puppalguda, Kokapet, VN Pally, Narsingi and Manchirevula were also proposed for the merger (TNN 2018a). ${ }^{22}$ However, just a few months later, the plan was dropped after Members of the Legislative Assembly (MLAs) from these areas came out in opposition to the tax implications of the merger. As TNN (2018b) reported, ruling party "leaders from the erstwhile Rangareddy districts protested saying that such a move would lead to higher taxes and turn the people against them."

It is worth noting that many of these settings do not merely adjoin the territory of the GHMC. ${ }^{23}$ In some cases, they are even tucked into it and host prominent real estate projects, e.g., the Reliance-led Hyderabad Trade Towers project in Manchirevula and Kokapet SEZ. ${ }^{24}$ These are sites of ambitious but delay-ridden anchor projects facilitated by state government agencies such as the state industrial infrastructure corporation and the metropolitan planning authority (Reddy 2018). 
56 As Table 1 shows, gram panchayats such as VN Pally and Tellapur were eventually partially or fully absorbed into newly formed municipalities in 2018. These municipalities are the third form of local bodies that characterize the speculative frontier. As Figure 8 shows, this stretch is buzzing with ongoing housing construction projects.

57 Proposed as a compromise solution, according to a 2018 news report, 18 new municipalities were formed in peri-urban Hyderabad, including shamshabad and Manikonda, Narsingi, Ameenpur and Tellapur. In a revealing move, the Department of Municipal Administration and Urban Development committed not to levy new taxes in the newly formed municipalities for at least a couple of years (Mahesh 2018).

Narsingi municipality, which hosted a population of over 25,000 even as of the 2011 Census, is a good example of such a settlement. Like its neighbors in Rajendranagar Mandal, Manikonda and Shamshabad, Narsingi avoided statutory status even as it met and exceeded census population norms (News2018 2011). ${ }^{25}$ Puppalguda, home to many high-end gated communities being developed by well-known real estate actors such as Prestige, may offer one window into the political economy of statutory status for these sites. Manchirevula, where locals went to Court to fight incorporation into the GHMC, is similarly the site of luxury villas and expansive plotted developments. ${ }^{26}$

What advantages do these municipalities offer compared to outright incorporation into the GHMC? In the case of Bangalore, scholars such as Kamath, Baindur and Rajan (2008) and Goldman (2011b) have argued that municipal expansion diluted representation as fewer elected representatives served much larger populations. However, as Sood and Kennedy (2020) have argued, smaller jurisdictions also allow for tighter control over public finances compared to the GHMC which pools revenues as well as expenditures across circles and wards. The "get what you pay for" principle of the IALA may not have an airtight application when it comes to the municipalities (Reynolds 2004). In effect, however, the smaller populations of the new municipalities and their far less efficient property tax collection apparatuses probably reduce diversions of revenues to areas outside their jurisdictions.

Worth noting is the fact that the GHMC was itself constituted by incorporating a large number of municipalities located on its periphery in 2007. Indeed, contestations around this annexation have continued over the past decade in places such as Manikonda, where both local panchayats and the industrial infrastructure corporation have resisted incorporation into the GHMC (Sood 2016; Kennedy and Sood 2019). Nonetheless, this sub-section has argued that the governance arrangements emerging and dissolving in this speculative frontier bear some imprint of real estate agendas.

61 Rouanet and Halbert (2016:9), among others, have carefully traced the extraordinary sway of local real estate developers and their "capacity to build contemporary cityscapes, along-or, as we will show, in competition-with public authorities." The entrepreneurial agendas of the Andhra Pradesh and now Telangana state government make it especially friendly to these interests and willing to instrumentalize urban governance in pursuit of the goals of urban growth (Kennedy and Zérah 2008; Sood and Kennedy 2020; Mitra 2018). The form of local government may thus represent one important dimension of such "self-empowerment." 


\section{Incongruent Jurisdictions}

62 estate agendas leave in this peri-urban geography. To understand the territorial configuration of this speculative frontier on the ground, there is no location better than Q City Road. Named after the high-end Technology Park located in the Financial District, under the "exceptional" IALA form of government, Q City Road connects ISB Road (named for the Indian School of Business) on the east to the erstwhile villages of Gowlidoddi to the west. Key to my argument is how this road juxtaposes the diversity of local government forms that shape the larger universe of speculative governance on this margin. In each direction, it connects disparate regimes of governance and collective goods provision.

Running North-South, alongside the Financial District, IT Parks and independent SEZs and IT campuses, ISB Road is a key artery in the premium spaces of the Nanakramguda IALA..$^{27}$ The property tax collections in the IALA largely support the high levels of road and other infrastructure within the zone (Kennedy and Sood 2019), reflected by the well-serviced and manicured spaces of the Financial District and IT Park. ${ }^{28}$ Emblematic of the globalized premium spaces promoted by the state government in the western Cyberabad development of Hyderabad, this is an arena of wide roads and high-quality infrastructures that will eventually house a major international consulate in Hyderabad, alongside hotels and national banks' headquarters (Sood 2016).

To the west, Q City road leads to the old village of Gowlidoddi, which was incorporated into the GHMC in 2007. Officially classified as a slum, large parts of Gowlidoddi are rapidly transforming into a service economy of small-time hotels, hostels, paying guest accommodations and retail and eateries that cater to the IT workforce of the area (Sood 2019). Hidden away in less conspicuous corners of Gowlidoddi are vast swathes of housing for lower-income migrants and locals who provide the housekeeping and domestic workforce for the Financial District and its neighboring SEZs and IT Parks. With the meteoric rise of real estate values in this area, occupation rights for the most vulnerable communities in the mass of villages incorporated into the municipal corporation in this vicinity-Nanakramguda, Gopanapalli, Gopanapalli Thanda, Gachibowli-have proved precarious (see Kennedy et al. 2020).

The poor-quality roads and water woes of the village/slum of Gowlidoddi testify to the splintered spatial geography of this frontier. Underlying these differences are the invisible lines across jurisdictional boundaries, both between the GHMC and the IALA but also those that separate the GHMC area from the gated communities in its midst (Sood 2019). Other evidence suggests other jurisdictions beyond these two may be in the mix, adding to the jurisdictional confusion in this terrain. ${ }^{29}$ Elsewhere towards the south of ISB Road and the so-called Anvaya Convention Road (named after a private convention centre $)^{30}$ is surreal geography that gives concrete imagery to the notion of the speculative frontier. Till 2015 and later, close to the ORR, Anvaya Convention Road was lined on either side by gated compounds housing nothing but wilderness (Figure 9 shows an example), real estate waiting to be realized in land value. ${ }^{31}$ The southern reaches of ISB Road also encompassed till recently a not-so-clandestine groundwater extraction operation on private (and erstwhile agricultural) lands close to the Outer Ring Road. ${ }^{32}$ 
Figure 9: A gated compound behind Hyderabad Financial District, 2015

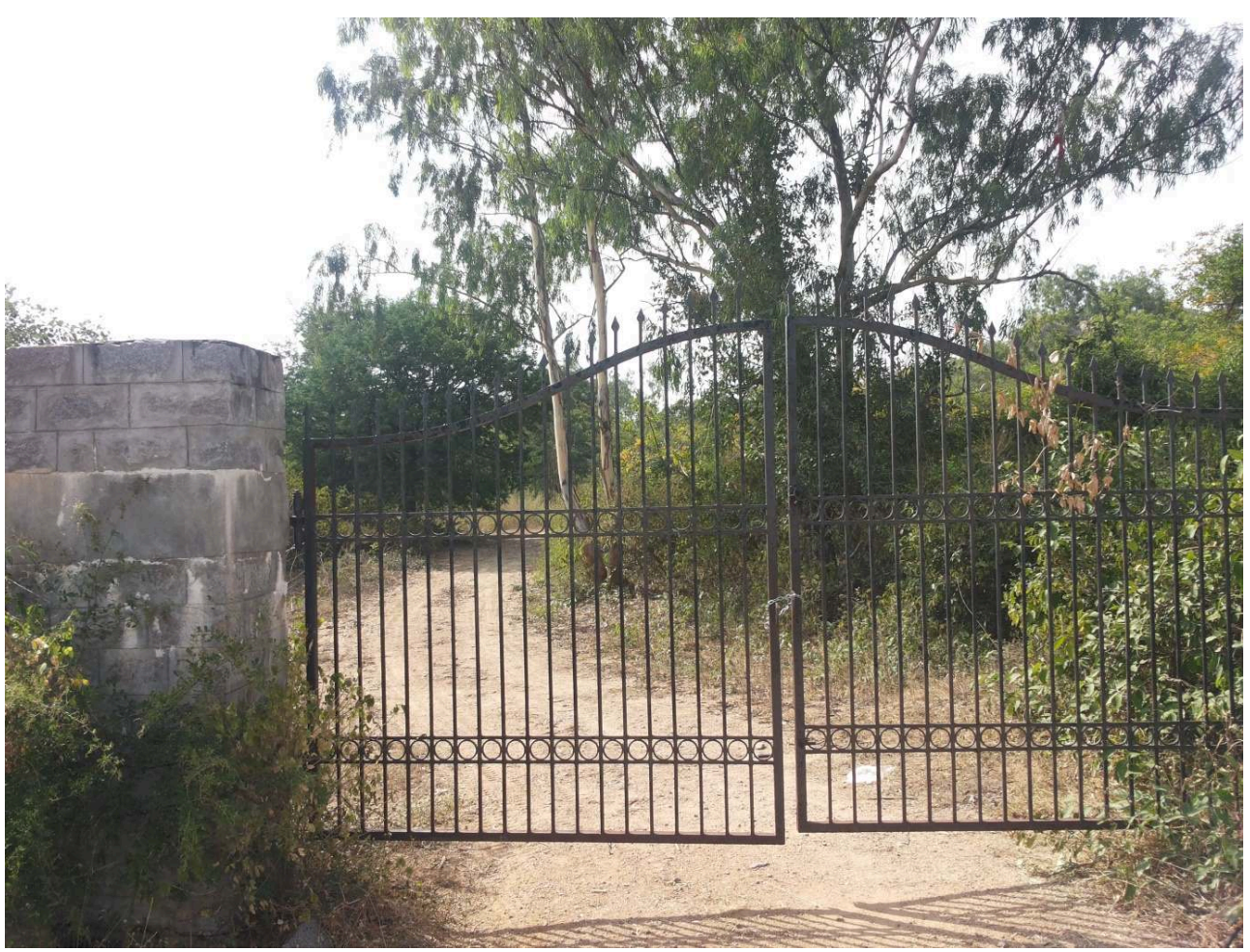

Image credit: A. Sood, 2015

At the same time, the multiplicity of governance modalities serves to create and maintain vastly different levels of service provision on water access, among other matters. Although water supply in most of western Hyderabad is supplied through a parastatal, the Hyderabad Metropolitan Water Supply and Sewerage Board, ${ }^{33}$ the high ramparts of the gated communities and IALA areas are protected from the worst water shortages. The most vulnerable communities on the other hand must resort to supply through tankers, which they can ill afford. It is worth noting the local water board office is located in the Financial District, impacting access to more distant communities. ${ }^{34}$ Similar scenes are echoed across the Cyberabad developments and their surrounds in Madhapur village (Das and Skelton 2019).

The central argument in this section has been that the primacy of real estate interests on Greater Hyderabad's speculative frontier is tied to jurisdictional multiplication and institutional voids which mark its territory. "Who is in charge?" is a question to which the answer remains obscure, allowing state actors considerable power without accountability. Channels for collective action or political mobilization by poor groups may be curbed by hazy jurisdictional boundaries and the information gaps they produce, as Kennedy et al. (2020) show.

\section{Conclusion: Speculative Peri-Urbanism}

68 This paper advances three distinct but interconnected theses about the speculative frontier. First, a pan-India mapping of the investment activity reveals a speculative frontier that is concentrated on metropolitan peripheries, creating new pan-India geographies of exclusionary urbanization (Kundu 2009; Balakrishnan 2020). 

transitional and specialized modes of urban government and these often valorize the interests of propertied groups at the expense of migrants and working-class communities. Shatkin (2017) asks, "Can the political empowerment of elites through the formation of new civic organizations break the power of 'vote bank' politics?" (p. 129). In response, this paper proposes that the mode of government in itself can function as an instrument for elites to counter occupancy urbanism and its street politics. If the "lack of institutional spaces for the adjudication of urban claims" in Indian politics instead force "urban spatial relations" to be settled through "collective action or ad hoc assertions of power" (Shatkin 2017:128), the events at Noida represent a decisive victory of political power exercised by the accumulation economy. the lack of institutional arrangements to manage and direct real estate-led growth to public ends generates jurisdictional interfaces that reflect and uphold patterns of urban splintering. On the other hand, a census town of Noida's size is by no means unique. Census (2011b) lists roughly 20 such census towns of over one lakh population, many of which are industrial townships. Also included in their ranks are cities such as Navi Mumbai Panvel Raigad (Census of India 2011b)

71 The salience of private Indian actors revealed in our database also has repercussions for the speculative frontier. As Rouanet and Halbert (2016) note, real estate actors in Bangalore have been influential in shaping the spatial course of the city by pushing the development of exurban areas but also by directing policy, planning priorities and even the imagery of the ideal city along certain lines (also Searle 2010). This paper argues that their influence in the entrepreneurial agendas of state governments also impacts modes of urban governance on the peri-urban frontier not only during, but also in the aftermath of construction.

Located on the edges of municipal boundaries and the larger metropolitan development areas, the speculative frontier is riddled with institutional interfacesand voids-across private and public agencies, such as development authorities or gated communities and a variety of local government forms. They typify India's urban predicament: "the Indian city remains undergoverned even as it is subjected to extensive (albeit ineffectual) planning and regulation" (Weinstein, Sami, and Shatkin 2014:43; quoted in Shatkin 2017:145). Territorial and functional disputes across as well as within multiple agencies-issues of internal and external governance (Sood 2015) constitute the defining features of a fraught and uneven speculative frontier.

This speculative frontier complicates the vision of auto-constructed peripheral urbanization offered by Caldeira (2017). Shaped by real estate dynamics, the governance of the speculative frontier has repercussions even for more organic and informal peri-urban growth. Regardless of the specific typology or multiplicity of urban governments, our two case studies would suggest that the speculative frontier is hostile territory for the occupancies that help realize the right to the city in urban India. The two scenarios of jurisdictional blurring, as in Greater Hyderabad, as also the lack of locally embedded and elected representation, as in Noida, hinder claim-making by vulnerable and migrant populations on the speculative frontier. Valorizing the rural and urban propertied classes, moreover, and often influenced by real estate interests, the makeshift and/or exceptional governments on the speculative frontier serve to 
undercut occupancy urbanisms (Benjamin 2008), as the unhappy outcome for the basti in Noida Sector 78 case demonstrates.

Connecting the dots across sometimes disconnected literatures, this paper has laid out an agenda for future work to attend, as Samanta (2014) advises, to the political economy of the transitional and exceptional forms of local government on the periurban frontier. Yet, the political question remains alive and ever-more relevant in this post-COVID world.

The scale of the infrastructure being constructed on the speculative frontier of metropolitan peripheries draws and relies on massive flows of migrant labor. Yet, what if any channels for protection, support and appeal do state apparatuses afford communities like Zohra Bibi's? The peri-urban may be heir to all the contestations and contradictions that beset the Indian city. Yet, the urban governance on the speculative frontier may also serve to undermine the possibility of citizenship for those who construct it.

\section{BIBLIOGRAPHY}

Arabindoo, Pushpa. 2009. "Falling Apart at the Margins? Neighbourhood Transformations in Periurban Chennai." Development and Change 40(5):879-901.

Bahl, Advitya. 2017. “Noida, Greater Noida Don't Need a Municipal Corporation.” DNA, December 17. Retrieved March 6, 2021 (https://www.dnaindia.com/delhi/report-noida-greater-noida-dont-need-a-municipal-corporation-2568227).

Balakrishnan, Sai. 2013. "Highway Urbanization and Land Conflicts: The Challenges to Decentralization in India." Pacific Affairs 86(4):785-811.

Balakrishnan, Sai. 2019. "Recombinant Urbanization: Agrarian-urban Landed Property and Uneven Development in India." International Journal of Urban and Regional Research 43(4):617-32.

Balakrishnan, Sai. 2020. “India's Migrant Crisis: Trapped in a COVID Spatial Rift.” Epicenter, May 15.

Benjamin, Solomon. 2000. "Governance, Economic Settings and Poverty in Bangalore." Environment and Urbanisation 12(1):35-56.

Benjamin, Solomon. 2007. “Occupancy Urbanism: Ten Theses.” Sarai Reader 7:538-63.

Benjamin, Solomon. 2008. "Occupancy Urbanism: Radicalizing Politics and Economy beyond Policy and Programs." International Journal of Urban and Regional Research 32(3):719-29.

Bhattacharya, Rajesh and Kalyan Sanyal. 2011. "Bypassing the Squalor: New Towns, Immaterial Labour and Exclusion in Post-colonial Urbanisation." Economic \& Political Weekly 46(31):41-48.

Bhide, Amita. 2014. “The Regularising State.” Economic \& Political Weekly 49(22):92-100.

Caldeira, Teresa P. 2017. "Peripheral Urbanization: Autoconstruction, Transversal Logics, and Politics in Cities of the Global South." Environment and Planning D: Society and Space 35(1):3-20. 
Census of India. 2011a. "District Census Handbook: Rangareddy," Town and Village Directory, Series-29, Directorate of Census Operations, Andhra Pradesh.

Census of India. 2011b. "Cities Having Population 1 Lakh and above, Table 2, Provisional Population Totals."

Census of India. 2011c. "Introduction, Concepts and Definitions, Jurisdictional Changes, RuralUrban Frame: Andhra Pradesh. Provisional Population Totals, Paper-2," Volume 1 of 2011. Rural and Urban areas, Andhra Pradesh, Series-29."

Coelho, Karen, Lalitha Kamath, and M. Vijayabaskar, eds. 2013. Participolis: Consent and Contention in Neoliberal Urban India. New Delhi: Taylor \& Francis.

Das, Diganta, and Tracey Skelton. 2020. "Hydrating Hyderabad: Rapid Urbanisation, Water Scarcity and the Difficulties and Possibilities of Human Flourishing." Urban Studies 57(7):1553-69.

Denis, Eric, Partha Mukhopadhyay, and Marie-Hélène Zérah. 2012. "Subaltern Urbanisation in India." Economic \& Political Weekly 47(30):52-62.

Desai, Renu, and Shachi Sanghvi. 2017. "Urban Planning, Governance and Infrastructural Violence: Water and Conflict in Bombay Hotel.” Economic \& Political Weekly 52(7):49-57.

Deccan Chronicle. 2016. "Telangana Sarpanches to Face Suspension for Issuing Approvals to Illegal Layouts.” Deccan Chronicle, July 21. Retrieved March 6, 2021 (https:// www.deccanchronicle.com/nation/current-affairs/210716/telangana-sarpanches-to-facesuspension-for-issuing-approvals-to-illegal-layouts.html).

Deekshith, Maddy. 2018. “Confusion over GHMC's $6^{\text {th }}$ Zone.” Deccan Chronicle, February 6. Retrieved March 6, 2021 (https://www.deccanchronicle.com/nation/current-affairs/060218/ confusion-over-ghmcs-6th-zone.html).

Dey, Abhishek. 2017. "In Noida, a Riot-like Situation over a Domestic Worker Puts the Focus on India's Bitter Class Chasm.” Scroll, July 13. Retrieved March 6, 2021 (https://scroll.in/article/ 843601 /in-noida-a-riot-like-situation-over-a-domestic-worker-puts-the-focus-on-indias-starkclass-chasm).

Dubey, Shruti. 2018. “Urban Transformations in Khora Village, NCR.” Economic \& Political Weekly 53(12):77.

Dupont, Veronique. 2016. "Secured Residential Enclaves in the Delhi Region: Impact of Indigenous and Transnational Models." City, Culture and Society 7(4):227-36.

Express News Service. 2019. "Separate Municipal Corporations for Noida, Greater Noida." The New Indian Express, August 8. Retrieved March 6, 2021 (https://www.newindianexpress.com/nation/ 2019/aug/08/separate-municipal-corporations-for-noida-greater-noida-2015853.html).

Express Web Desk. 2017. "Noida Society Violence: Mahesh Sharma Sides with Family as Authorities Raze Shanties.” Indian Express, July 18. Retrieved March 6, 2021 (https:// indianexpress.com/article/india/noida-society-violence-mahesh-sharma-sides-with-family-asauthorities-raze-shanties/).

Follmann, Alexander. 2015. "Urban Mega-projects for a 'World-class' Riverfront: The Interplay of Informality, Flexibility and Exceptionality along the Yamuna in Delhi, India." Habitat International 45:213-22.

Gajendran, V. 2016. “Chennai's Peri-urban: Accumulation of Capital and Environmental exploitation." Environment and Urbanization ASIA 7(1):113-31. 
Ghertner, D. Asher. 2011. "Rule by Aesthetics: World-class City Making in Delhi." Pp. 279-306 in Worlding Cities: Asian Experiments and the Art of Being Global, edited by A. Roy and A. Ong. Oxford: Wiley Blackwell.

Gillespie, Tom. 2020. “The Real Estate Frontier." International Journal of Urban and Regional Research. 44(4):599-616.

Ghosh, Sahana and Rimple Mehta. 2017. "Under the Sign of Security: Why the Bogey of 'the Illegal Bangladeshi Immigrant' is So Powerful across Urban Indian Homes." Kafila, July 27. Retrieved March 6, 2021 (https://kafila.online/2017/07/27/under-the-sign-of-security-why-the-bogey-ofthe-illegal-bangladeshi-immigrant-is-so-powerful-across-urban-indian-homes-sahana-ghoshrimple-mehta/\#more-36485).

Ghoshal, Anirudha and Aditi Vatsa. 2017. "Noida Violence: Worlds under the Ivory Tower." Indian Express, July 17. Retrieved March 6, 2021 (https://indianexpress.com/article/india/noidaviolence-worlds-under-ivory-tower-4753795/).

Goldman, Michael. 2011a. "Speculative Urbanism and the Making of the Next World City." International Journal of Urban and Regional Research 35(3):555-81.

Goldman, Michael. 2011b. "Speculating on the Next World City." Pp. 246-47 in Worlding Cities: Asian Experiments and the Art of Being Global, edited by A. Roy and A. Ong. Oxford: Wiley Blackwell.

Gupta, Monobina. 2017. “In 'Moderne' India, Social Apartheid Is Sparking Millions of Small Mutinies.” The Wire, July 26. Retrieved March 6, 2021 (https://thewire.in/politics/noidainequality-zohra-bibi-social-apartheid).

Gururani, Shubhra, and Rajarshi Dasgupta. 2018. "Frontier Urbanism: Urbanisation beyond Cities in South Asia. Economic \& Political Weekly 53(12):41-45.

Halbert, Ludovic, and Hortense Rouanet. 2014. "Filtering Risk Away: Global Finance Capital, Trans-scalar Territorial Networks and the (Un)making of City-regions: An Analysis of Business Property Development in Bangalore, India." Regional Studies 48(3):471-84.

Idiculla, Matthew. 2016. “New Regimes of Private Governance.” Economic \& Political Weekly 51(17): 103.

Kennedy, Loraine. 2007. "Regional Industrial Policies Driving Peri-urban Dynamics in Hyderabad, India." Cities 24(2):95-109.

Kennedy, Loraine. 2014. The Politics of Economic Restructuring in India: Economic Governance and State Spatial Rescaling. Abingdon, Oxon and London: Routledge.

Kennedy, Loraine, and Ashima Sood. 2016. “Greenfield Development as Tabula Rasa." Economic \& Political Weekly 51(17):41.

Kennedy, Loraine, Ashima Sood, Debdatta Chakraborty, and Ram Mohan Chitta. 2020.

"Interrogating Data Justice on Hyderabad's Urban Frontier: Information Politics and the Internal Differentiation of Vulnerable Communities." Information, Communication \& Society. doi: 10.1080/1369118X.2020.1851388

Kennedy, Loraine, and Marie-Hélène Zérah. 2008. “The Shift to City-centric Growth Strategies: Perspectives from Hyderabad and Mumbai." Economic \& Political Weekly 43(39):110-17.

Kundu, Amitabh. 2009. "Exclusionary Urbanisation in Asia: A Macro Overview." Economic \& Political Weekly 44(48):48-58.

Kundu, Ratoola. 2016. "Making Sense of Place in Rajarhat New Town." Economic \& Political Weekly 51(17):93. 
Maanvi. 2017. "Mahagun Moderne: A Concrete Island, Many Truths and Class Conflict." The Quint, July 21. Retrieved March 6, 2021 (https://www.thequint.com/news/india/mahagun-moderneclass-conflict-urban-noida).

Mahesh, K. 2018. “TRS Government Junks Plan to Merge Villages with GHMC.” Times of India, April 15. Retrieved March 6, 2021 (https://timesofindia.indiatimes.com/city/hyderabad/trsgovernment-junks-plan-to-merge-villages-with-ghmc/articleshow/63767145.cms).

Mitra, Sudeshna. 2018. “Roads to New Urban Futures.” Economic \& Political Weekly 53(49):57.

Mohan, Shriya. 2017. "Fear and Loathing in Moderne Times." Hindu BusinessLine, July 21. Retrieved March 6, 2021 (https://www.thehindubusinessline.com/blink/know/fear-andloathing-in-moderne-times/article9781571.ece).

Nair, Janaki. 2015. "Indian Urbanism and the Terrain of the Law." Economic \& Political Weekly 50(36):54-63.

News18. 2011. “30 Villages to Be Merged with GHMC.” News18, August 27. Retrieved March 6, 2021 (https://www.newindianexpress.com/cities/hyderabad/2011/aug/27/30-villages-to-be-mergedwith-ghmc-285121.html).

North, Douglass C. 1991. “Institutions.” Journal of Economic Perspectives 5(1):97-112.

Pradhan, K.C. 2013. “Unacknowledged Urbanisation.” Economic \& Political Weekly 48(36):43.

Raman, Bhuvaneswari. 2016. "Reading into the Politics of Land." Economic \& Political Weekly 51(17): 77.

Reddy, U. Sudhakar. 2018. "Telangana Has 28 Dud SEZs, Highest in India; Govt to Take Back Land.” The Times of India, July 28. Retrieved March 6, 2021 (https://timesofindia.indiatimes.com/ city/hyderabad/telangana-has-28-dud-sezs-highest-in-india-govt-to-take-back-land/ articleshow/65172891.cms).

Reynolds, Laurie. 2004. “Taxes, Fees, Assessments, Dues, and the Get What You Pay for Model of Local Government.” Florida Law Review 56:373-445.

Rouanet, H., and L. Halbert. 2016. "Leveraging Finance Capital: Urban Change and SelfEmpowerment of Real Estate Developers in India." Urban Studies 53(7):1401-23.

Samanta, Gopa, and Akash Banerjee. Forthcoming. "Industrial Zone to New Skycity: The (Un) Making of India's First Aerotropolis." India's Greenfield Urban Future: The Politics of Land, Planning and Infrastructure, edited by A. Sood and L. Kennedy.

Samanta, Gopa. 2014. "The Politics of Classification and the Complexity of Governance in Census Towns.” Economic \& Political Weekly 49(22):55-62.

Sami, Neha. 2013. "From Farming to Development: Urban Coalitions in Pune, India." International Journal of Urban and Regional Research 37(1):151-64.

Schindler, Seth, and Brij Kishore. 2015. "Why Delhi Cannot Plan its 'New Towns': The Case of Solid Waste Management in Noida." Geoforum 60:33-42.

Searle, L.G. 2010. "Making Space for Capital: The Production of Global Landscapes in Contemporary India.” PhD dissertation, Department of Anthropology, University of Pennsylvania.

Sen, Rajyasree. 2017. “Why Zohra Bibi’s Story is not Unusual." LiveMint, July 14. Retrieved March 6, 2021 (https://www.livemint.com/Opinion/obMyJqaoxf66E9GpLoncVL/Why-Zohra-Bibis-storyis-not-unusual.html). 
Shatkin, Gavin. 2016. "The Real Estate Turn in Policy and Planning: Land Monetization and the Political Economy of Peri-urbanization in Asia.” Cities 53:141-49.

Shatkin, Gavin. 2017. Cities for Profit: The Real Estate Turn in Asia's Urban Politics. Ithaca and London: Cornell University Press.

Shaw, Annapurna. 2018. "Suburbanization in Asia." Pp. 100-109 in The Routledge Companion to The Suburbs, edited by B. Hanlon, and T.J. Vicino. New York: Routledge.

Sinha, Meenakshi. 2017a. "RWA Body Opposes Noida Municipality Plan." Times of India, October 28. Retrieved March 6, 2021 (https://timesofindia.indiatimes.com/city/noida/rwa-body-opposesnoida-municipality-plan/articleshow/61280736.cms).

Sinha, Meenakshi. 2017b. "RWA Federation, RLS Demand Municipal Corporation for Noida." Times of India, December 20. Retrieved March 6, 2021 (https://timesofindia.indiatimes.com/city/noida/ rwa-federation-rls-demand-municipal-corporation-for-noida/articleshow/62151540.cms).

Sood, Ashima, and Loraine Kennedy. 2020. "Neoliberal Exception to Liberal Democracy? Entrepreneurial Territorial Governance in India." Territory, Politics, Governance 8(1):23-42.

Sood, Ashima. 2015. "Industrial Townships and the Policy Facilitation of Corporate Urbanisation in India." Urban Studies 52(8):1359-78.

Sood, Ashima. 2016. "Rule by Exception? Zoning Technologies in Hyderabad." Working paper. Delhi: Centre de Science Humaines.

Sood, Ashima. 2019. “Industrial Policies Make Indian Cities.” URBANET, August.

South Asia Citizens' Web (SACW). 2017. "India: Violence of Class in Noida-Crackdown after Protest by Domestic Workers.” Retrieved March 28, 2020 (http://www.sacw.net/ article13390.html).

Special Correspondent. 2013. "More Rangareddy, Medak Villages into GHMC." The Hindu, March 11. Retrieved March 6, 2021 (https://www.thehindu.com/news/cities/Hyderabad/more-rangareddy-medak-villages-into-ghmc/article4497860.ece).

Staff Reporter. 2013. “In Manikonda, Any Deed Is Valid.” The Hindu, February 10; updated June 13, 2016. Retrieved March 6, 2021 (https://www.thehindu.com/news/cities/Hyderabad/inmanikonda-any-deed-is-valid/article4397644.ece).

The Hindu Staff Reporter. 2017. "Noida Razes Shanties of Those Who Vandalised Apartments." The Hindu, 18 July. Retrieved March 6, 2021 (https://www.thehindu.com/news/cities/Delhi/ noida-razes-shanties-of-those-who-vandalised-apartments/article19298713.ece).

Times-News Network (TNN). 2020. "Civic Body for Noida? Officials Hold Meeting." Times of India, February 15. Retrieved March 6, 2021 (https://timesofindia.indiatimes.com/city/noida/civicbody-for-noida-officials-hold-meeting/articleshow/74143263.cms).

TNN. 2013a. "Illegal Layouts Galore in Manikonda, Poppalguda." Times of India, February 10. Retrieved March 6, 2021 (https://timesofindia.indiatimes.com/city/hyderabad/illegal-layoutsgalore-in-manikonda-poppalguda/articleshow/18424164.cms).

TNN. 2013b. “15 Villages Merged with Greater Hyderabad.” Times of India, September 1. Retrieved February 15, 2021 (http://timesofindia.indiatimes.com/articleshow/22194326.cms).

TNN. 2018a. "IT Corridor to Soon Merge with Greater Hyderabad Municipal Corporation." Times of India, January 12. Retrieved March 6, 2021 (https://timesofindia.indiatimes.com/city/hyderabad/ it-corridor-to-soon-merge-with-ghmc/articleshow/62467438.cms). 
Xie, Liubing. 2021. “Assemblages of Living Together: Residential Cohabitation in Peri-urban Areas of Chengdu and Hyderabad." SAMAJ 26. Retrieved April 28, 2021 (https:// journals.openedition.org/samaj/7334).

Zérah, Marie Hélène, Stéphanie Tawa Lama-Rewal, Veronique Dupont, and Basudeb Chaudhuri. 2011. "Introduction: Right to the City and Urban Citizenship in the Indian Context." Pp. 1-11 in Urban Policies and the Right to the City in India: Rights, Responsibilities and Citizenship, edited by M. H. Zérah, V. Dupont, and S. Tawa Lama-Rewal. New Delhi: Centre de Sciences Humaines.

\section{NOTES}

1. This paper owes a debt of gratitude to many organizations and individuals. The database presented in this paper was funded by a Research Grant from Azim Premji University. Tarun Jain collaborated on this project. Ashish Andhale and Leja Mathew provided early research assistance. Sneha Kuraikose was an intern. I am very grateful to Prerna Dokania for all her help in creating the database. Shreya Basu created the maps. Parts of this work were presented at ISEC, Bangalore, RC21, Delhi and IIAS, Shimla. Some of the fieldwork in the Hyderabad leg of this study was conducted as part of a Research Fellowship from the Centre de Sciences Humaines in Delhi. Loraine Kennedy's mentorship, collaboration and insights have been invaluable in the research agenda that informs this paper. Ram Mohan Chitta, Debdatta Chakraborty, Rajkumar Paseddula and RaviTeja Sangeetha were marvellous young collaborators. Thank you also to Gopa Samanta for her comments on an early draft and to Ram Mohan Chitta for his close reading of later drafts.

2. However, exceptional ULBs such as Cantonment Boards may also lead to statutory status (Pradhan 2013).

3. A rare example comes from Halbert and Rouanet (2014), which provided a thematically and geographically narrower lens focused on financialized real estate. These authors created a database of foreign direct investment (FDI) deals in business property between 2005 and 2011. Shaw and Satish (2007:153) also employed data from the same CMIE source but focused on different parameters, excluding "investments in the residential sector" since they represent "only asset creation and no capacity creation."

4. CapEx Knowledge Base

5. Project status can be coded into several different discrete categories. The categories of "outstanding" and "shelved" were derived variables, created by combining relevant categories. Capex Knowledge Base, "What is project status?"

6. Although the CapEx database contains rudimentary location data, latitude-longitude data was obtained from another CMIE database.

7. Due to limitations of space, this section does not enter into the definitional criteria and analysis conducted on UIMS.

8. Publicly available data from the respective urban development authorities was used to identify districts and villages falling in these metropolitan regions.

9. The data for India's urban population in 2018 is taken from Index Mundi, Retrieved March 6, 2021 (https://www.indexmundi.com/facts/india/urban-population). Census (2011b) data is more dated.

10. Calculations by the author based on Census 2011 data on 53 Indian million-plus urban agglomerations.

11. All maps were created using QGIS software by Shreya Basu.

12. Our analysis also points to a deeper set of questions about the nature of the urban in India. Recent scholarship has highlighted the role of organic "subaltern" urbanization in determining the urban "map" of India (Denis, Mukhopadhyay, and Zérah 2012). The scale of investment on the 
speculative frontier seems to lend truth to the conventional wisdom that city-making continues to be a matter of concerted investment in India (Bhagat 2004:65). It also helps explain the metrocentric bias of existing scholarship on the peri-urban frontier (cf. Gururani and Dasgupta 2018).

13. While many of these developments are part of the database presented in the previous section, separating out projects based in Noida's jurisdiction is not possible, in the absence of geospatial data.

14. Retrieved March 6, 2021 (https://noidaauthorityonline.in/en/page/about-noida)

15. Though the discussion remains outside the scope of this paper, this model resonates with Ferguson's (1990) notion of an anti-politics.

16. Particularly murky is this context is the position of the FONRWA, which first came out against and then in favour of the municipal corporation (Sinha 2017a; TNN 2017b).

17. Nonetheless, the Mahagun Moderne case also shows how the "street politics of the need economy" have been frustrated and repressed (Bhattacharya and Sanyal 2011:47).

18. The Greater Hyderabad database is a subset of the larger database presented in Section II.

19. The ensuing fight over the jurisdiction and revenue between the state industrial infrastructure corporation and the GHMC is documented in Kennedy and Sood (2019) and Sood and Kennedy (2020).

20. The "draft delimitation of wards" given on the websites of the respective municipalitiesManikonda, Narsingi, Tellapur-were consulted.

21. The spellings of this settlement vary in official and non-official sources. Hence the abbreviation VN Pally is used.

22. There were also plans to introduce another zone in the Municipal Corporation to incorporate 30 such villages including "Poppalguda, Kokapet, Vattinagulapally, Narsingi and Manchirevula" (Deekshith 2018)

23. Manikonda municipality website.

24. Telangana State Industrial Infrastructure Corporation, "Development of Trade Tower \& Business District.” Retrieved February 23, 2021 (https://tsiic.telangana.gov.in/pdf/CBD.pdf). Reliance Infrastructure, "Real Estate Development for a New India." Retrieved February 23, 2021 (https://www.rinfra.com/real-estates-sez).

25. Narsingi Municipality website.

26. Field visit, Manchirevula, February 2018.

27. It must be added, however, that not all campuses along ISB Road fall within the Nanakramguda IALA jurisdiction, though others such as Wipro SEZ may be subject to specialized tax regimes from time to time.

28. Interview, YSR Bhavan, 8 January 2016. Layouts of TSIIC properties in the Cyberabad Zone, including the Financial District, were provided to the author.

29. The new Narsingi Municipality Draft Delimitation of Wards shows Old Gowlidoddi village as part of Vattinagullapally 2 ward. The fact that part of Gowlidoddi lies under a different jurisdiction was also mentioned at an interview at Gowlidoddi Angadwadi in January 2016. However, a Serilingampally Circle map from the GHMC shows Gowlidoddi lying within it.

30. Parts of the Puppalguda village define the boundaries of Manikonda Municipality, according to the Draft Delimitation of Wards.

31. Primary fieldwork and documentation, November 2015, July 2017.

32. Primary fieldwork and documentation, November 2015, July 2017.

33. Interview, Gowlidoddi Angadwadi, January 2016.

34. Fieldwork as part of the project "Data justice through the prism of occupation rights on the urban fringe: a case study in Hyderabad, India," March 2019. 


\section{ABSTRACTS}

What is urban about the peri-urban? This paper explores the speculative frontier of volatile real estate investments and exceptional and transitional forms of local government that characterize this peri-urban terrain. By definition lying outside the municipal norm of the metropolitan core, the peri-urban frontier that is outlined in this analysis through a novel database of large-scale investments in residential and commercial capacity across India represents an arena where the statutory definition of the urban, i.e., elected municipal governance, is politically contested. Drawing on case studies of Greater Hyderabad and Noida in the Delhi National Capital Region, this paper traces the divergent modalities of peri-urban government. In Greater Hyderabad, the trajectory leads to institutional fragmentation. In Noida, it results in the concentration of powers in non-representative agencies. In either scenario, I argue that the speculative frontier remains hostile to claim-making by poor groups through the channels of occupancy, even as it empowers propertied classes.

\section{INDEX}

Keywords: urban governance, urban local bodies, peri-urban, census towns, Noida, Greater Hyderabad, real estate

\section{AUTHOR}

\section{ASHIMA SOOD}

Anant National University, Ahmedabad 